\title{
Using Group Approaches to Promote Healthy Aging
}

\section{Leidiene Ferreira Santos ${ }^{1}$ and Daniella Pires Nunes ${ }^{2 *}$ \\ ${ }^{1}$ Faculty of Nursing, University Federal of Goiás, Brazil \\ ${ }^{2}$ School of Nursing, University of São Paulo, Brazil}

Aging is a vital and singular process that is experienced differently across individuals depending on the social and cultural beliefs of the particular societies. It is also considered the individual life time of each one, which expires in objectified finiteness of biological death [1].

Aging appears now as a worldwide phenomenon. Improvements in technology, allied with better conditions in health care, have given man the opportunity to enjoy a longer life. Providing quality to the additional years of life is a challenge, however, particularly because in these times of economical and technological progress we have been facing a shift from personal, face-to-face interaction, to a more digital pattern of communication affecting both family and friends relationships.

Importantly, the elderly population is exposed to various biological, cognitive and psychological changes such as disabilities, loss of social utility, memory loss, slow speed of processing, physical fatigue, reduced physical endurance, diseases , dementia, senility, mental degeneration, inactivity, low self-esteem, appearance wrinkles, prejudice, disrespect, asexuality, dependence, helplessness, exclusion of life's pleasures, family rejection, isolation, abandonment, loneliness, sadness, depression and institutionalization [2].

In this sense, considering the assumptions of humanization and comprehensiveness of care, the quality of life of older people is an eminent necessity in the context of health care, and to achieve it, social and health workers must rethink care issues devoted to elderly customers, in order to promote healthy aging, active participation in decision-making processes and the enhancement of the social role of the elderly.

So it is necessary to create strategies that incorporate the demands of the aging population, as well as promoting support networks and rehabilitation of the elderly in the society. In this scenario, the use of group approaches has proven to be an effective strategy to reduce social isolation and promote active aging.

Take part in group activities leads to better learning, provides a proper environment for sharing feelings and expectations, can influence changes in behavior through health education and prevention and provides socialization and emotional support [3].

When properly delivered to the community, the group service facilitates the collective construction of knowledge and reflection on the reality experienced by its members, and can be used as a potential tool of health promotion for the elderly, taking into account both biological and psychosocial human dimensions related to the healthdisease dualism and collaborating to achieve an active and healthy aging [4].

Through the participation in group activities, older adults have the opportunity to expand the boundaries of their personal worth, experience new perspectives in life and take part in pleasurable activities, make plans about future life projects and acquire and / or maintain strategies to deal with the aging process [5].

The experience of sharing experiences in group dynamics promotes a network of solidarity and support that favors the transformation of personal experiences on collective experiences, making participants able to learn new habits from shared experiences and clarifications made by the members of the group [6].

Importantly, the use of group technology as a strategy for health intervention should be more widespread and considered among the professionals in this area, since it requires no substantial budget and, optimize the service as it allows multiple people to benefit from the intervention, attends to the real needs of the people and allows the professional to assume a position horizontally in relation to the demands of its participants, in favor of the joint construction of knowledge [3].

Moreover, the implementation of this technology as a resource to assist people requires the knowledge of the nature of the group, its operation and the relationships within individuals and between group and society [7].

It is important to realize that there are no foolproof recipes and techniques for the construction of care group, but it is up to the coordinator to be alert to the nuances of this specific field and be prepared for this task, in order to minimize the chances of failure and increase the chances of success in using group activities to promote better quality of life for the elderly.

\section{References}

1. Horta ALM, Ferreira DCO, Zhao LM (2010) Envelhecimento, estratégias de enfrentamento do idoso e repercussões na família. Rev Bras Enferm 63: 523528.

2. Guerra ACLC, Caldas CP (2010) Dificuldades e recompensas no processo de envelhecimento: a percepção do sujeito idoso. Ciênc saúde coletiva 15 2931-2940.

3. Santos LF, Oliveira LMAC, Munari DB, Peixoto MKAV, Silva CC, et al. (2012) Grupo de suporte como estratégia para assistência de enfermagem à família de recém-nascidos hospitalizados. Rev eletr enferm.

4. Nogueira ALG (2012) O grupo é o nosso remédio: lições de um grupo de promoção da saúde de idosos. Dissertation

5. Morais ONP (2009) Grupo de idosos: atuação da psicogerontologia no enfoque preventivo. Psicologia Ciência E Profissão 29: 846-855.

6. Oliveira NF, Munari DB, Bachion MM, Santos WS, Santos QR (2009) Fatores terapêutios em grupo de diabéticos. Rev esc enferm USP 43: 558-565.

7. Lewin K (1948) Problemas de dinâmica de grupo. São Paulo: Cultrix.

*Corresponding author: Daniella Pires Nunes, University of São Paulo, Departamento de Epidemiologia - Estatística, Estudo SABE (Saúde, bem estar e envelhecimento), Avenida Doutor Arnaldo, 715-1ªndar, CEP 01246-904-São Paulo-SP-Brazil, Tel: (55-11) 3061-7931; E-mail: dpiresnunes@yahoo.com.br

Received March 12, 2013; Accepted March 15, 2013; Published March 19, 2013

Citation: Santos LF, Nunes DP (2013) Using Group Approaches to Promote Healthy Aging. J Gerontol Geriat Res 2: e119. doi:10.4172/2167-7182.1000e119

Copyright: ( $) 2013$ Santos LF, et al. This is an open-access article distributed under the terms of the Creative Commons Attribution License, which permits unrestricted use, distribution, and reproduction in any medium, provided the original author and source are credited. 